\title{
Charles Taylor, A Secular Age, Cambridge, Mass./London: The Belknap Press of Harvard University Press, 2007,

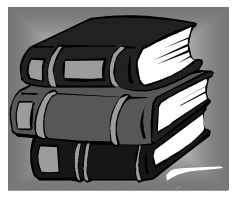

$874 \mathrm{hlm}$.

Charles Taylor-yang lahir pada 1931 di Kanada-adalah salah seorang filosof kontemporer berbahasa Inggris paling terkenal. Ia menjadi guru besar di Montreal dan mengajar juga di Oxford. Hampir 20 tahun sesudah dua jilid bukunya, Sources of the Self: The Making of Modern Identity (1989), memperoleh perhatian besar, Taylor menerbitkan buku A Secular Age, sebuah karya lebih raksasa lagi, yang oleh Robert N. Bellah disebut "salah satu buku terpenting semasa hidup saya." Buku ini menceritakan sejarah sekularisasi di Barat dan dengan demikian juga sejarah perkembangan spiritualitas intelektual Barat dalam 500 tahun terakhir.

Yang langsung mengesankan adalah luasnya pengetahuan Taylor. Taylor akrab dengan seluruh filsafat dan pemikiran yang mengungkapkan intelektualitas Barat. Uraiannya, di satu pihak, menarik garis-garis besar, di lain pihak, memperlihatkan garis-garis itu dengan penelurusan rinci terhadap apa yang ditulis oleh tokoh-tokoh intelektual, para filosof, teolog, sastrawan dan penyair. Yang juga menarik, Taylor memperlihatkan bagaimana "apa yang semula dipikirkan hanya oleh para elit, menjadi milik umum masyarakat-masyarakat seluruhnya" (hlm. 299).

Perkembangan yang ditelusuri Taylor betul-betul mengherankan. Dalam pertanyaan Taylor: "Apa yang berubah antara tahun 1500 di mana hampir tidak mungkin orang tidak percaya (pada Allah), dan tahun 2000 di mana tidak hanya terdapat banyak orang ateis yang bahagia, melainkan sebaliknya di lingkungan-lingkungan tertentu iman menantang lagi sebagai aliran amat kuat?" Bagaimana Eropa Kekristenan Latinkekristenan yang pernah memakai bahasa Latin di Eropa Tengah dan Barat, dunia yang sejak abad ke-16 terbagi dalam Katolik dan Protestanmenjadi Barat di mana "iman, bahkan bagi mereka yang yakin, hanya merupakan salah satu kemungkinan bagi manusia di antara banyak kemungkinan lain?" (hlm. 3). 
Penulis di sini hanya dapat menarik kembali garis-garis besar cerita Taylor yang pada hakekatnya merupakan cerita tentang perubahan dari dunia di mana keselamatan manusia terasa tergantung dari kekuatankekuatan yang gaib di seberang ke suatu dunia yang disenchanted (entzaubert dalam bahasa Max Weber), di mana alam gaib tidak memainkan peran apa pun dalam hidup dan pekerjaan orang sehari-hari.

Tahap pertama perkembangan itu adalah revolusi religius abad ke16, revolusi Protestantisme. Revolusi itu melahirkan apa yang oleh Taylor disebut Cerita Induk Reformasi (Reform Master Narrative) yang menuntut agar setiap anggota umat menjadi orang Kristiani sungguh-sungguh. Yang dimaksud adalah bahwa apa yang sebelumnya hanya dituntut dari para imam, rohaniwan dan rohaniwati, dalam Protestantisme dituntut dari semua anggota Gereja (Gereja Katolik baru merealisasikan RMN itu dalam Konsili Vatikan II). Sekarang kesadaran individu menentukan takar mutu kekristenan (seperti 200 tahun kemudian Immanuel Kant menempatkan kesadaran individu sebagai unsur kunci moralitas). Dari suatu realitas sosial dan kultural, agama menjadi hubungan pribadi dengan Kristus. Dalam rangka penghayatan itu segala macam roh dan kekuatan gaib, di luar Tuhan, kehilangan perannya.

Perubahan lebih mendasar lagi dibawa 200 tahun kemudian oleh Pencerahan. Atas nama rasionalitas legitimitasi segala tatanan hirarkis gerejawi dan politis mulai ditolak. Muncul suatu keyakinan normatif baru: masyarakat bertujuan agar semua warga saling menguntungkan. Kalau dulu "perang dan penjarahan" menjadi cita-cita budaya para ksatria, maka sekarang "pertumbuhan dan kemakmuran menjadi nilai kunci" (hlm. 129). Moralitas masyarakat pemula kapitalisme itu berdasarkan sikap bahwa manusia harus "saling menghormati dan (selalu) memperbaiki diri" (hlm. 129). "Perdagangan dan kegiatan ekonomis" dipandang sebagai "jalan menuju perdamaian" (hlm. 180).

Dalam penghayatan baru ini apa saja yang pada agama berbau "tahayul," "fanatisme," dan "semangat berlebihan" (hlm. 239) ditolak (dan karena Gereja Katolik tidak mengikuti perubahan itu, selama 200 
tahun ia dicemoohkan dan dibenci sebagai benteng kekolotan oleh Protestantisme dan oleh elit intelektual di negara-negara Katolik sendiri). Penghayatan itu secara mendasar mengubah pengertian tentang Allah. Allah tidak lagi yang dekat pada kita, yang dapat diminta bantuannya dan yang sering melakukan intervensi di dunia demi keselamatan kita. Suatu aliran yang disebut deisme memahami Allah sebagai Sang Perancang yang pada permulaan merancang tananan alam dan masyarakat yang rasional, yang kemudian mempertahankan diri dan berkembang sesuai dengan rasionalitas internalnya itu tanpa perlu ada intervensi Ilahi lagi. Taylor di sini bicara tentang "cerita kesesatan intelektual" (the intellectual deviation story) yang intinya adalah paham bahwa dunia bersama masyarakat merupakan suatu tatanan imanen tertutup. Tidak mengherankan bahwa dalam waktu singkat elit intelektual Pencerahan akan menolak dimensi transenden sama sekali. Kalau alam raya dan masyarakat berlangsung tanpa intervensi sama sekali dari Yang Ilahi, maka seorang Perancang Ilahi pada permulaan juga tidak dibutuhkan. Maka lahirlah apa yang oleh Taylor disebut "humanisme eksklusif," sikap di mana pencapaian kebahagiaan manusia menjadi tujuan kehidupan dan pencapaian tujuan itu menjadi tanggung jawab eksklusif manusia sendiri; jadi tanpa acuan pada suatu realitas transenden. Pada waktu itu ateisme dan agnostisisme (anggapan bahwa tentang realitas di luar alam raya tidak dapat diketahui sesuatu apa pun secara rasional) masih terbatas pada golongan kecil orang-orang intelektual. Tetapi kereta api sekularisasimenghilangnya acuan pada realitas transenden dari jangkauan kehidupan biasa - tidak dapat dihentikan lagi. Dua ratus tahun kemudian sekularisasi teresapkan oleh masyarakat luas.

Akan tetapi, menghilangnya dimensi Ilahi dari wawasan sehari-hari bukan perkembangan linear searah, melainkan perkembangan ke araharah kontradiktif. Adalah sangat menarik bahwa Taylor yakin bahwa agama tidak akan sampai menguap habis di alam sekularisasi. Bukan hanya agama-agama tetap mempertahankan diri dengan menempatkan diri secara baru dalam dunia yang memang sudah bebas dari unsur-unsur gaib; tetapi, menurut Taylor, di luar agama, di tengah-tengah ketidak- 
percayaan, di bawah permukaan masih tetap ada suatu kerinduan akan sesuatu dari luar dunia ini. Jadi, menurut Taylor, ateisme bukan satusatunya bentuk sekularisasi. Berhadapan dengan "pengandaian dasar (di zaman sekularisasi) bahwa pandangan-pandangan religius-transenden adalah keliru atau sekurang-kurangnya tanpa dasar yang masuk akal" Taylor melihat "suatu masa depan lain," yaitu "bahwa dalam hidup agama kita, kita menanggapi suatu realitas transenden, dan itu sesuai dengan realitas" (hlm. 769). Ada suatu persepsi di bawah permukaan bahwa masih ada juga realitas atau dimensi yang lebih besar dari pada realitas kasatmata. "Cerita yang menarik bukan semata-mata cerita tentang kemunduran (agama), melainkan juga cerita mengenai penempatan baru Yang Kudus atau Spiritual ke dalam hidup individual dan sosial" (hlm. 437).

Di sini penulis harus membatasi diri pada beberapa percikan dari kekayaan masalah yang dibahas rinci oleh Taylor. Taylor, misalnya, mengangkat sesuatu yang menjadi masalah bagi etika pasca Pencerahan (yang juga diangkat oleh Alasdair MacIntyre dan Iris Murdoch). Ia bertanya, dari mana manusia tersekularisasi dapat mengambil motivasi untuk mengikuti kode-kode kelakuan etis modernitas yang begitu diyakininya - yang memang cukup menuntut - kecuali kalau diakui bahwa manusia menyadari suatu tuntutan atau tantangan yang melampaui realitas empiris belaka? Filsafat moral pasca Pencerahan berobsesi dengan kode-kode kelakuan bermoral, tetapi melalaikan dimensi rasa. Apakah, misalnya, perasaan ngeri kalau kita menyaksikan bagaimana anak kecil dibunuh, atau kebaikan hati yang berakar di hati nurani tidak mempunyai arti bagi etika? Taylor ternyata dekat dengan apa yang dimaksud orang Jawa dengan rasa. Ia juga mempersoalkan epistemologi yang sejak Kant juga tidak dapat menjelaskan apa yang terjadi kalau manusia mengerti sesuatu. Pembahasan lain yang juga sangat menarik adalah tentang bagaimana masyarakat pasca religius menangani kematian.

Bagi penulis, ada tiga uraian panjang yang paling menarik. Yang pertama bertolak dari pertanyaan "mengapa manusia modern begitu sulit 
percaya kepada Allah" (hlm. 439), atau, sebaliknya, di mana sebenarnya letak daya tarik materialisme ilmiah, anggapan bahwa tidak ada sesuatu di luar atau di seberang alam raya kita? Di sini pun jawaban Taylor menantang. Menurutnya, materialisme ilmiah sebenarnya dianut bukan karena alasan-alasan ilmiah, melainkan karena alasan-alasan etis! Menolak realitas di seberang dirasakan sebagai kejujuran, sebagai tanda kepribadian yang matang, sebagai tanda keberanian, tanda sifat kelaki-lakian berhadapan dengan ketakutan-ketakutan dan sentimentalitas infantil orang beragama. Namun Taylor juga menunjuk pada faktor yang pragmatis, yaitu pada revolusi konsumerisme. Kemewahan yang ditawarkan oleh sistem perekonomian Barat sesudah perang dunia II, yakni tawaran bahwa apa saja yang diinginkan - yang di zaman-zaman sebelumnya sama sekali di luar capaian orang biasa - dapat diperoleh asalkan orang bisa membayar, memasukkan pengejaran kebahagiaan (the pursuit of happiness) yang sejak zaman Pencerahan semakin dirasakan sebagai hak asasi manusia yang paling diyakini, ke dalam persneling amat tinggi, dengan akibat bahwa nafsu konsumsi menyapu ke samping segala pertimbangan etis dan religius lebih luas.

Yang kedua-yang membuat penulis ini berpikir - adalah uraian Taylor tentang hubungan antara agama dan kekerasan sepanjang 19 halaman (hlm. 685-703). Taylor di situ mengangkat suatu segi paling gelap dalam keberadaban manusia sebelum ia "dicerahkan" oleh Pencerahan. "Sejak permulaan keberadaban manusia," begitu Taylor, "agama dan kekerasan terkait amat erat" (hlm. 688). Taylor berbicara tentang "mekanisme kambing hitam" (hlm. 686), tentang suatu paham gelap bahwa dengan membunuh atas nama agama, atau dalam rangka suatu ritus keagamaan, manusia-ya orang yang membunuh-membersihkan diri dari dosa maupun dari kutukan dari "seberang." Bagi penulis Katolik ini, pertanyaan Taylor menusuk: bagaimana mungkin bahwa keberadaban Kristiani-yang berkembang dari ajaran injili yang seluruhnya berfokus pada kasih sayang dan tidak mengenal kekerasan sama sekali-dapat menemukan dan mengaktualisasikan kembali persecution, penindasan, penganiayaan dan pembunuhan, seperti misalnya halnya anti-semitisme atau perang salib? 
Yang ketiga adalah apa yang ditulis Taylor tentang agama di zaman sekularisasi (hlm. 505-539), serta implikasi-implikasi situasi baru itu bagi Kristianitas (hlm. 728-778). Di sini termasuk juga analisis-analisis, nasihatnasihat, dan kritik-kritik halus Taylor-yang adalah seorang Katolik aktif-yang dialamatkan ke Gereja Katolik, khususnya juga menyangkut sikapnya terhadap seksualitas (hlm. 495 -504).

Kesimpulan dari uraian Taylor yang dapat ditarik adalah bahwa sekularisasi merupakan sebuah proses yang kompleks, yang menggagalkan segala penjelasan sederhana dan linear. Alam sosial tersekularisasi sendiri adalah kompleks. Di satu pihak, alam itu merupakan puncak humanisme eksklusif warisan Pencerahan, tetapi, di lain pihak, eksklusivisme itu ditantang oleh suatu "kelaparan spiritual" (hlm. 680) yang tetap terarah ke sesuatu di "seberang." "Cerita dominan sekularisasi yang cenderung mempersalahkan agama-agama atas banyaknya kesusahan dunia kita lama-kelamaan akan semakin tidak dipercayai lagi" (hlm. 770). Namun, kalau agama mau mempertahankan diri maka wakil-wakilnya harus belajar menjadi rendah hati. Perlu ditambah bahwa Taylor sedikit pun tidak memasuki pertanyaan yang banyak dikemukakan di Indonesia dan dijawab secara berbeda-beda, yaitu, apakah perkembangan 500 tahun di dunia Kristianitas Latin (Katolik dan Protestan), jadi di “Barat," dari dunia yang penuh dengan roh-roh dan di mana ateisme sepertinya mustahil menjadi sebuah dunia humanisme eksklusif di mana untuk sebagian makin besar warga kontemporer realitas Ilahi, realitas di "seberang," dianggap tidak ada, atau sekurang-kurangnya tidak mempunyai fungsi atau hak normatif.

Buku Charles Taylor ini amat pantas dibaca dan betul-betul menantang. Kalau kita membacanya - yang tidak perlu secara tergesa-gesa - kita akan merasa mendapat wawasan yang luas, kita menjadi mengerti apa yang memotori modernitas. Buku ini betul-betul sebuah master piece. (Franz Magnis-Suseno, Guru besar emeritus, Sekolah Tinggi Filsafat Driyarkara, Jakarta). 